非環状フェノール一ホルマリン系オリゴマーと四級アンモニウム塩との相互作用

伊藤和 明, ${ }^{*}$ 三木啓光, 大場好弘

\title{
Interaction between Acyclic Phenol-Formaldehyde Oligomers and Quaternary Ammonium Ions
}

\author{
Kazuaki ITo, ${ }^{*}$ Hiromitsu MikI, and Yoshihiro OHBA \\ Department of Chemistry and Chemical Engineering, Faculty of Engineering, Yamagata University, \\ 4-3-16, Jonan, Yonezawa 992-8510, Japan
}

(Received January 17, 2002; Accepted March 13, 2002)

\begin{abstract}
The interaction between acyclic phenol-formaldehyde oligomers (1) and quaternary ammonium ions (5) was investigated by ${ }^{1} \mathrm{H}-\mathrm{NMR}$ spectroscopy. From the induced chemical shift change of $\mathbf{5}$ in the presence of $\mathbf{1}$, the cation- $\pi$ interaction between the $\mathrm{N}^{+-}\left(\mathrm{CH}_{3}\right)_{3}$ moiety of 5 and the $\pi$-base of $\mathbf{1}$ occurs during the formation of the complex. Another important observation is that the $\mathrm{OH}$ proton signals of $\mathbf{1}$ are considerably broadened upon addition of $\mathbf{5}$, indicating that hydrogen bonding occurs between exchangeable protons of $\mathbf{1}$ and iodide anion of $\mathbf{5}$. These interactions play an important role in the binding of 5 .
\end{abstract}

Key words — phenol—formaldehyde oligomer; quaternary ammonium ion; cation- $\pi$ interaction; hydrogen bonding

\section{緒 言}

生体内の情報伝達物質の 1 つであるアセチルコリ ンはその構造内に四級アンモニウムイオン部分を有 している. このアセチルコリンを認識する膜タンパ ク質の認識部位や，アセチルコリンエステラーゼの 活性部位には, 芳香族アミノ酸残基が数多く配置さ れており，四級アンモニウムイオンと芳香環との間 に働くカチオンー $\pi$ 相互作用が重要な役割を果たし

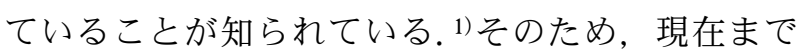
に四級アンモニウムイオンを認識する人エレセプ ターとしてシクロファン誘導体を用いた研究がいく つか報告されている. ${ }^{2-7)} し か し ，$ 生体内タンパク 質の四級アンモニウムイオン認識部位は, シクロフ アンのように整然と芳香族アミノ酸が配置していな いこと, 及び多くのタンパク質では, 基質との複合 体形成により構造変化を引き起こす場合があること を考えるとシクロファンの非環状型が興味あるレセ プター分子として候補に挙がってくる. ${ }^{4,5)}$ そこで我 々は, 非環状フェノールーホルマリン系オリゴマー

山形大学工学部物質化学工学科

e-mail: itokazu@yz.yamagata-u.ac.jp
をホスト分子として四級アンモニウム塩との相互作 用について検討した。

\section{結果と考察}

フェノール誘導体（1）と四級アンモニウム塩（5) との相互作用を ${ }^{1} \mathrm{H}-\mathrm{NMR}$ スペクトルにおける誘起 化学シフト変化 $\left(\Delta \delta=\delta-\delta_{\text {free, }}\right.$ ここで, $\delta_{\text {free }}$ は 5 の 化学シフト值, $\delta$ は 1 存在下での 5 の化学シフト 值）から検討した. p-tert-ブチルフェノール（1a) 及び非環状フェノールーホルマリン系オリゴマー $(\mathbf{1 b}, \mathbf{1 c})$ 存在下, 四級アンモニウム塩（5a）のプ ロトンの化学シフト值はすべて高磁場へシフトした (Table 1).とりわけ $N$ - メチル及び $N$ - メチレン部 分が大きく高磁場へシフトしたことから, 四級アン モニウムイオン部分がフェノール誘導体（1）の芳 香環上に位置していると考えられる. この時, 単量 体（1a）に比ベオリゴマー（1b, 1c）の方がより大 きな誘起化学シフト変化を引き起こした.さらに, $\mathbf{1 b} \cdot \mathbf{5 a}$ の NOE 実験から, 1b の芳香環及びメチレ ン水素と 5a の- $\mathrm{N}\left(\mathrm{CH}_{3}\right)_{3}$ メチル水素間に大きな $\mathrm{NOE}$ が観測され，5a の-N $\left(\mathrm{CH}_{3}\right)_{3}$ メチル基が $\mathbf{1 b} の$ 芳香環に近接した位置にあることが示された。一 方, 対応する $O$-メチル体 $(\mathbf{2 a}-\mathbf{2 c})$ 存在下での $\mathbf{5 a}$ 
Table 1. Chemical Shift Changes $(\Delta \delta)$ in $\mathbf{5}$ Induced by Added $\mathbf{1}^{\text {a) }}$

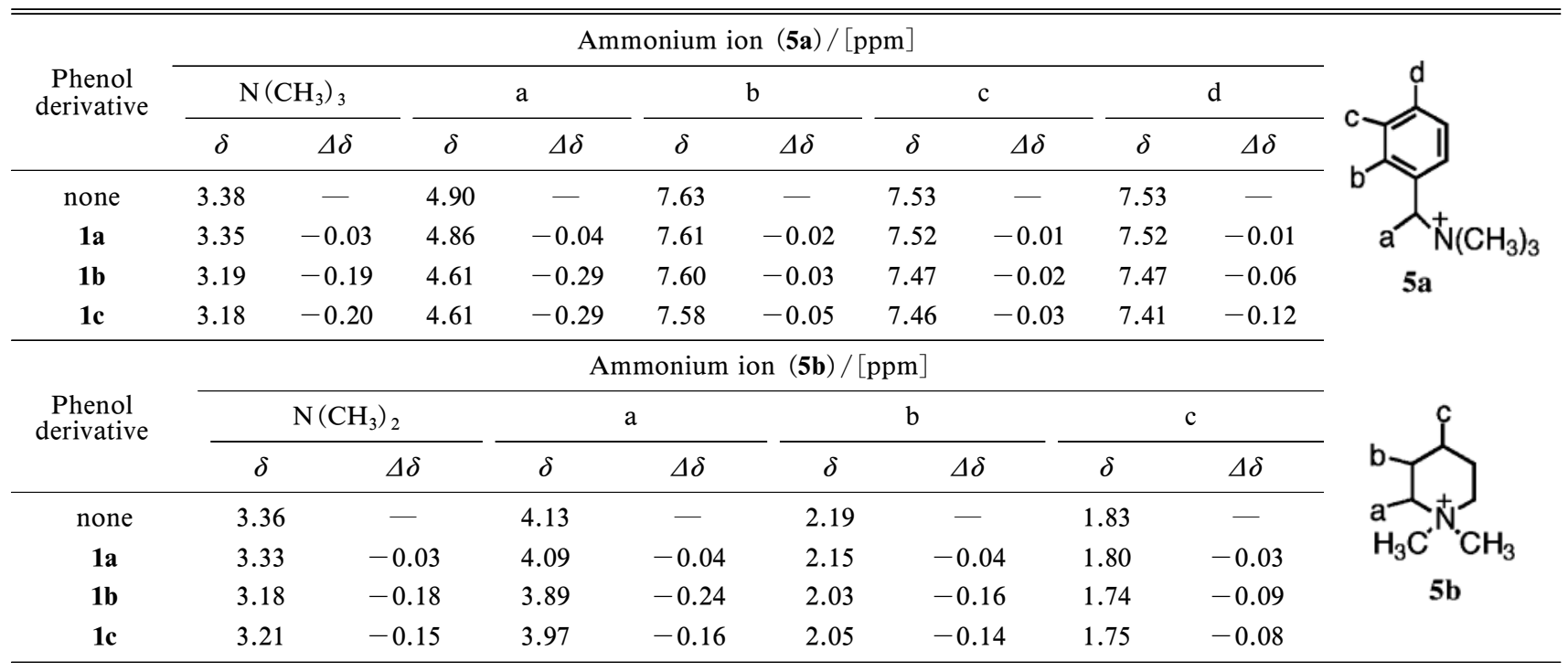

a) at $20^{\circ} \mathrm{C}$ in $\mathrm{CDCl}_{3},[1]=[5]=10 \mathrm{~mm}$, -denotes the shift to higher magnetic field.

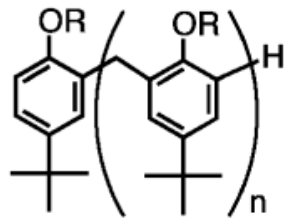

1a: $\mathrm{n}=0, \mathrm{R}=\mathrm{H}, \quad 2 \mathrm{a}: \mathrm{n}=0, \mathrm{R}=\mathrm{Me}$, 1b: $n=1, R=H, 2 b: n=1, R=M e$, 1c: $n=2, R=H \quad 2 c: n=2, R=M e$

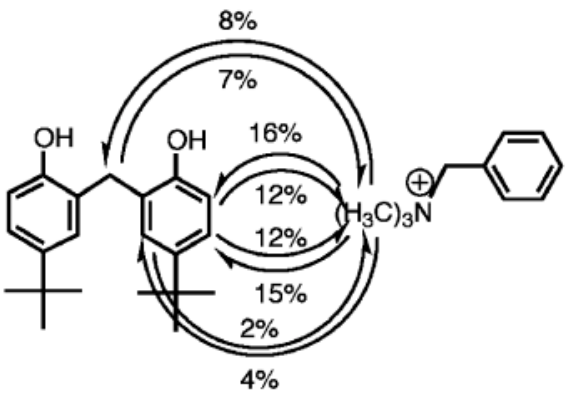

Fig. 2. NOE Correlation between $\mathbf{1 b}$ and $\mathbf{5 a}$

の化学シフト変化はすべて $0.01 \mathrm{ppm}$ 以下と大変小 さなものであった．同様の傾向は，アンモニウム塩 （5b）を用いた場合においても観測された，以上の 結果より，四級アンモニウム塩との相互作用におい て，1 の芳香環 $\pi$ 面とフェノール性水酸基が重要な

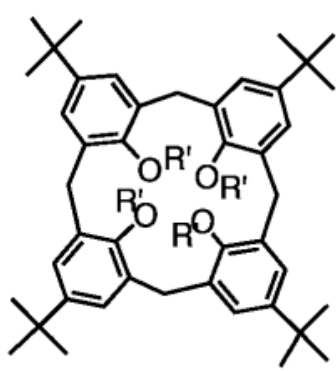

3: $\mathrm{R}^{\prime}=\mathrm{H}, \mathbf{4}: \mathrm{R}^{\prime}=\mathrm{Me}$

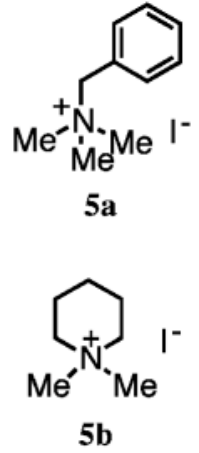

Fig. 1.
役割を果たしていることが示された.

一方，アンモニウム塩（5）存在下での 1 の ${ }^{1} \mathrm{H}-$ NMR スペクトル変化は, 1 の水酸基の吸収が著し くブロード化し，フェノール環の $o$ - 位は $+0.04-$ $+0.23 \mathrm{ppm}$ 低磁場シフトしたが，他の吸収はすべ て $-0.01--0.13 \mathrm{ppm}$ 高磁場へシフトした（Fig. 3). その変化の程度は単量体 (1a)に比べオリゴマー $(\mathbf{1 b}, 1 \mathrm{c})$ の方がより大きくシフトした. カリック ス [4]アレーン誘導体において, 隣接する 2 つの エノール環が anti 配置にある場合（alternate 配座） よりも syn 配置にある場合（cone 配座）の方が, 芳香環水素及び $p$ - 位置換基の水素が高磁場に観測

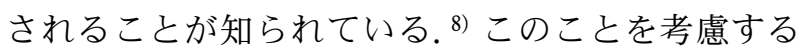
と, 5 存在下, 1 の化学シフト值が高磁場へシフト したのは 1 が 5 との錯体形成に伴いそれぞれのフェ 


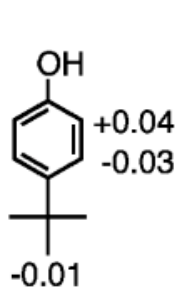

$1 \mathbf{a} \cdot \mathbf{5 a}$

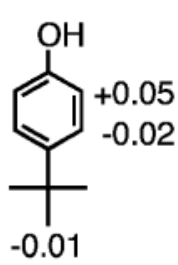

$\mathbf{1 a}-\mathbf{5 b}$

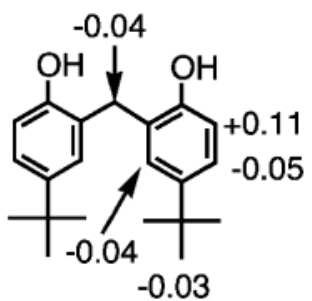

$1 \mathbf{b}-\mathbf{5 a}$

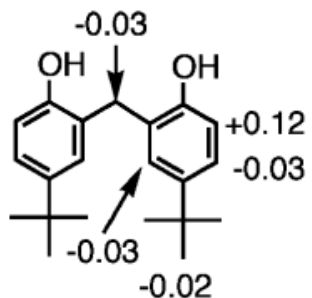

$1 \mathbf{c}-5 \mathbf{b}$

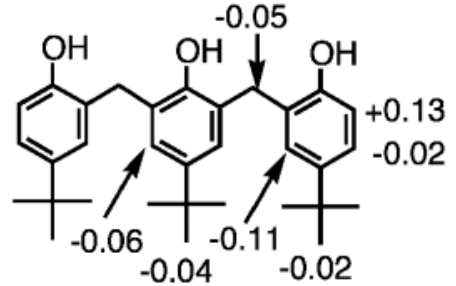

$1 c-5 a$

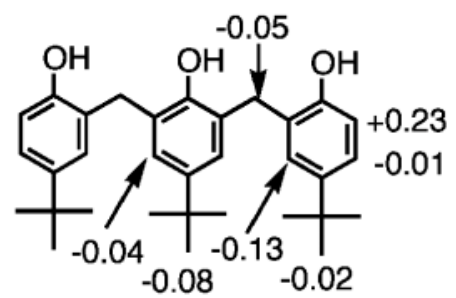

$\mathbf{1 c}-\mathbf{5 b}$

Fig. 3. Chemical Shift Changes of 1a, 1b, 1c Induced by Added 5 at $20^{\circ} \mathrm{C}$ in $\mathrm{CDCl}_{3}$ $([\mathbf{1}]=[\mathbf{5}]=10 \mathrm{~mm}$, -denotes the shift to higher magnetic field $)$.

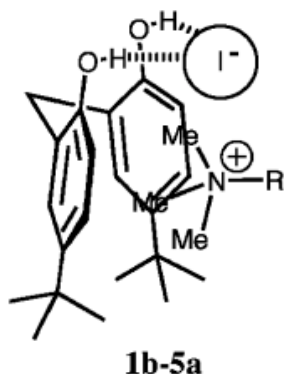

Fig. 4. Plausible Structure of the Complex $(\mathbf{1 b}-\mathbf{5 a})$

ノール環が syn 配置を取つたためと考えられる。一 方，1 の水酸基の吸収は，低温 $\left(-20^{\circ} \mathrm{C}\right)$ ではそれ ぞれ観測され（ $\delta_{\mathrm{OH}}=5.07 \mathrm{ppm} \quad(\mathbf{1 a}) ; 7.59 \mathrm{ppm}$ (1b) ; 9.15 (2H) , 9.58 (1H) ppm (1c)), 5 の添加に より 1 の水酸基の吸収は $+0.1-+0.2 \mathrm{ppm}$ 程低磁 場シフトした $\left(\delta_{\mathrm{OH}}=5.26 \mathrm{ppm}(\mathbf{1 a} \cdot \mathbf{5 a}) ; 7.83 \mathrm{ppm}\right.$ $(\mathbf{1 b} \cdot \mathbf{5 a}) ; 9.26(\mathbf{2 H}), 9.65(\mathbf{1 H}) \mathrm{ppm}(\mathbf{1 c} \cdot \mathbf{5 a}))$. こ の低磁場シフトは， 1 のフェノール性水酸基が $\mathbf{5}$ の ヨウ素アニオンと水素結合を形成したためと考えら れ，4）錯体形成に伴いそれぞれのフェノール環の水 酸基が同方向を向くという上述の予測を支持してい る. 以上の結果を基に，推定される錯体 $(\mathbf{1 b} \cdot \mathbf{5 a})$ の構造を Fig. 4 に示した.

一方，対応する環状化合物（3）の存在下， 5 の 誘起化学シフト変化について検討したが, ほとんど 変化が認められなかった $(\Delta \delta<0.01 \mathrm{ppm})$. 環状化
合物（3）はフエノール性水酸基を有するものの強 い分子内水素結合を形成している。 そのため $\mathbf{3}$ が $\mathbf{5}$ のヨウ素アニオンと水素結合を形成するためには, この分子内水素結合を解裂しなければならないため エネルギー的に不利であると考えられる. また， 3 は，その構造単位であるフェノールの $p$ - 位に嵩高 い tert-ブチル基があるためキャビティーは完全に ブロックされている. そのため $\mathbf{3}$ と $\mathbf{5}$ の間でのカチ オン $\pi$ 相互作用は期待できないものと考えられ る. 以上の理由から $\mathbf{3}$ は $\mathbf{5}$ と相互作用できなかった ものと考えられる. 3 の水酸基をすべてメトキシ化 した環状 $O$-メチル体（4）を用いた場合において も 5 との相互作用はほとんど認められなかった。

錯体 (1・5）の化学量論比を Job's 法9)により検 討したところ，1a 及び $\mathbf{1 b}$ の場合においては，0.5 のモル分率のところで極大值を与えたことから 1 : 1 錯体を形成していると考えられる (Fig. 5)。一方, 1c では，その極大值が約 0.4 であることから，1： 1 錯体のみならず複数の錯体が系中に存在している と予想される.

$1 \mathbf{b}$ と $5 \mathbf{a}$ との錯体形成について非線形最小二乗 法10)により会合定数（Ka）を求めたところ $42 \pm 11$ $\mathrm{M}^{-1}$ であった(Fig. 6)。これは, 環状のシクロファ ン類とアンモニウム塩との錯体形成による会合定数 に比べ若干小さいものの, 非環状型フェノールーホ ルマリン系二量体がアンモニウム塩のホスト分子と 


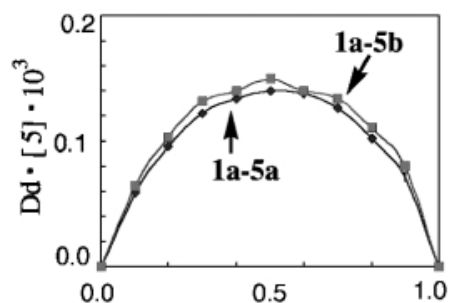

$[\mathbf{1 a}] /([\mathbf{1 a}]+[\mathbf{5}])$

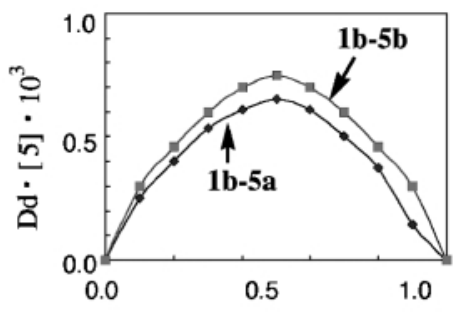

$[\mathbf{1 b}] /([\mathbf{1 b}]+[\mathbf{5}])$

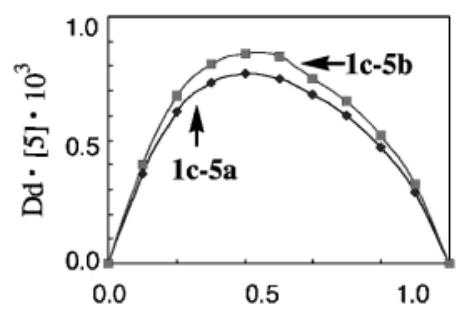

$[\mathbf{1 c}] /([\mathbf{1 c}]+[\mathbf{5}])$

Fig. 5. Job's Plot in the Complexation of $\mathbf{1}$ with $\mathbf{5}$

[5] is total concentration of $\mathbf{5}$, and $\Delta \delta$ is the shift (ppm) of the methyl resonance of $\mathbf{5}$ induced by the addition of $\mathbf{1}$. Total concentration of $\mathbf{1}$ plus $\mathbf{5}$ is maintained at $10 \mathrm{~mm}$.

して挙動することが明らかとなった. ${ }^{11)}$

\section{実 験 の 部}

NMR スペクトル測定は Varian INOVA500によ り行い, 測定に用いた重クロロホルムは水素化カル シウムで乾燥後, 常圧蒸留し使用した. フェノール 一ホルマリン系オリゴマー $\left(\mathbf{1}^{12)}, 2^{13)} ， 3^{14)}, 4^{15)}\right)$ 及 びアンモニウム塩 $(\mathbf{5})^{16)}$ の合成は文献記載の手法に より合成した.

錯体（1・5）の化学量論比を求める実験（Job’s plot 法) ${ }^{9)}$

$\mathbf{1}$ と $\mathbf{5}$ の濃度の和を一定 $([\mathbf{1}]+[\mathbf{5}]=10 \mathrm{mM})$ に保 ち, そのモル比 $([\mathbf{1}] /([\mathbf{1}]+[\mathbf{5}])=0.0,0.1,0.2$, $0.3,0.4,0.5,0.6,0.7,0.8,0.9,1.0)$ を連続的に変化 させる.このとき, 錯体の濃度（[1・5]）が最大を 与えるモル比が化学量論に対応している. 錯体の濃 度は, $[\mathbf{1} \cdot \mathbf{5}]=\Delta \delta \cdot[\mathbf{5}]$ より求めた。ここで $\Delta \delta$ は, 5 の $N$ - メチル基の化学シフト変化值を用いた.

錯体（1b・5a）の会合定数（Ka）を求める実験 (非線形最小二乗法)

濃度が $0.0119 \mathrm{mmol} / 1$ である 5a の重クロロホルム 溶液（700 $\mu \mathrm{l} ）$ 中へ，濃度が $0.0826 \mathrm{mmol} / 1$ である 1b の重クロロホルム溶液を，0，10，50，100，150， $200,300,400,500,1000 \mu 1$ づつ加え, それぞれの ${ }^{1} \mathrm{H}$ -NMR スペクトルを測定した。この時，5aの-N $\left(\mathrm{CH}_{3}\right)_{3}$ のメチル基の化学シフト值の変化量 $(\Delta \delta)$ を縦軸に, $5 \mathrm{a}$ と $1 \mathrm{~b}$ の濃度比 $[\mathbf{5 a}] /[\mathbf{1 b}]$ を横軸にと り滴定曲線（Fig. 6）を得た。この滴定曲線に対し て文献記載の非線形最小二乗法により会合定数 (Ka) を求めた. ${ }^{10)}$

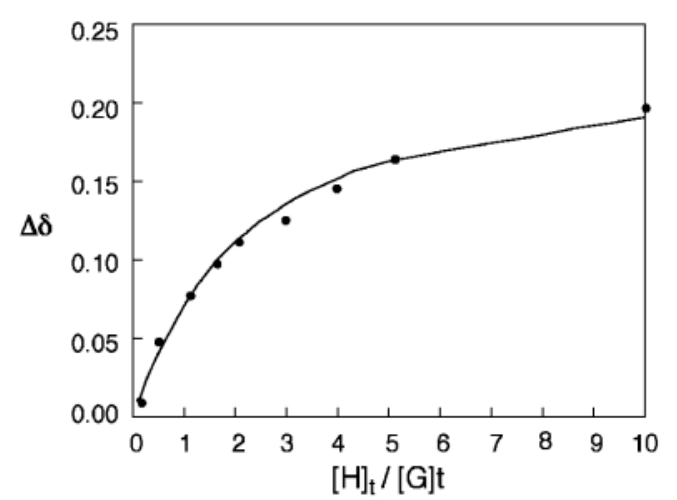

Fig. 6. ${ }^{1} \mathrm{H}-\mathrm{NMR}$ Titration of $\mathbf{1 b}$ with $\mathbf{5 a}$ in $\mathrm{CDCl}_{3}(\mathrm{~T}=293$ $\mathrm{K})$

Points are experimental and curves are calculated by non-linear regression.

\section{REFERENCES}

1) Ma J. C., Dougherty D. A., Chem. Rev., 97, 1303-1324 (1997).

2) Koh K. N., Araki K., Ikeda A., Otsuka H., Shinkai S., J. Am. Chem. Soc., 118, 755-758 (1996).

3) Arnecke R., Böhmer V., Cacciapaglia, R., Cort A. D., Mandolini L., Tetrahedron, 53, 4901-4908 (1997).

4) Jeong K.-S., Hahn K.-M., Cho Y. L., Tetrahedron Lett., 39, 3779-3782 (1998).

5) Roelens S., Torriti R., J. Am. Chem. Soc., 120, 12443-12452 (1998).

6) Arduini, A., Pochini A., Secchi A., Eur. J. Org. Chem., 2325-2334 (2000).

7) Arduini A., Giorgi G., Pochini A., Secchi A., Ugozzoli F., J. Org. Chem., 66, 8302-8308 (2001).

8) Gutsche C. D., Bauer L. J., J. Am. Chem. 
Soc., 107, 6052-6059 (1985).

9) Ogoshi H., Hayashi T., "Encyclopedia of Experimental Chemistry, Vol. 27, Bioorganic,' ed. by The Chemical Society of Japan, Maruzen Co., Ltd., Tokyo, 1991, pp. 19-25.

10) Hirose K., J. Incl. Phenom., 39, 193-209 (2001).

11) Araki K., Shimizu H., Shinkai S., Chem. Lett., 205-208 (1993).

12) Sone T., Ohba Y., Yamazaki H., Bull. Chem. Soc. Jpn., 62, 1111-1116 (1989).

13) Ito K., Ohba Y., Shinagawa E., Nakayama S.,
Takahashi S., Honda K., Nagafuji H., Suzuki A., Sone T., J. Heterocycl. Chem., 37, 14791489 (2000).

14) Gutsche C. D., Iqbal M., Org. Synth., Collect. Vol. VIII, 75-77 (1993).

15) Gutsche C. D., Dhawan B., Levine J. A., No K. H., Bauer L. J., Tetrahedron, 39, 409-426 (1983).

16) Cope A. C., Ciganek E., Fleckenstein L. J., Meisinger M. A. P., J. Am. Chem. Soc., 82, 4651-4655 (1960). 